\title{
Innendørs risikofylt lek: Muligheter for spenning og variasjon $i$ barnehagens lekemiljøer?
}

\author{
Rasmus Kleppe, ${ }^{1 \star}$ Ole Johan Sando ${ }^{2}$ og \\ Ellen Beate Sandseter Hansen ${ }^{2}$ \\ ${ }^{1}$ OsloMet - Storbyuniversitetet; ${ }^{2}$ Dronning Mauds Minne Høgskole for barnehagelarer- \\ utdanning
}

\begin{abstract}
Sammendrag
Risikofylt lek er en form for lek som kan bidra til både barns trivsel og utvikling, men som det er lite forsket på. I denne studien har vi undersøkt ulike aspekter ved risikofylt lek i barnehagers innemiljø. Studien baserer seg på videoobservasjon av 65 barn i alderen 3-5 år, fra syv barnehager, i perioder hvor barna var frie til å leke som de selv ville. Videoobservasjonene ble gjort i to faser, høsten 2017 (T1) og høsten 2018 (T2), og det endelige datamaterialet besto av 770 tominutters videoobservasjoner. Basert på observasjonene i T1 ble det gjennomført en intervensjon for å styrke de eksisterende fysiske lekemiljøene. Intervensjonen ble utviklet og gjennomført som et samarbeid mellom forskerne og ansatte i barnehagene. Effektene av intervensjonen ble observert i T2. Datamaterialet ble analysert med deskriptiv statistikk og regresjonsanalyser. Resultatene viser at barn lekte risikofylt innendørs, særlig lek med høyde og boltrelek/lekeslåssing, og at den risikofylte leken hovedsakelig foregikk på tumleareal og i garderoben. Resultater knyttet til intervensjonen viser at barnehagene som etablerte et integrert tumleareal hadde en $ø$ kning av risikofylt lek innendørs. I tillegg viser resultatene at både jenter, gutter og barn i ulike aldre tok i bruk tumlearealene til risikofylt lek etter intervensjonen. Totalt sett demonstrerer denne studien muligheter for å skape spennende og mer varierte lekemuligheter innendørs i barnehagen.
\end{abstract}

\section{Nøkkelord: Barnehage; lekemiljø; risikofylt lek; tumleareal}

Mottatt: Juni, 2020; Antatt: Oktober, 2020; Publisert: Desember, 2020

\begin{abstract}
Indoor risky play: Opportunities for excitement and variety in the ECEC play environments?

Risky play is a form of play that can contribute to both children's well-being and development, but there is a lack of research on the topic. In this study, we have investigated various aspects of
\end{abstract}

^Korrespondanse: Rasmus Kleppe, e-post: rask@oslomet.no

(C) 2020 R. Kleppe, O. J. Sando \& E. B. S. Hansen. This is an Open Access article distributed under the terms of the Creative Commons Attribution 4.0 International License (https://creativecommons.org/licenses/by-nc/4.0/), allowing third parties to copy and redistribute the material in any medium or format and to remix, transform, and build upon the material for any purpose, even commercially, provided the original work is properly cited and states its license.

Citation: R. Kleppe, O. F. Sando E E. B. S. Hansen. «Innendors risikofylt lek: Muligheter for spenning og variasjon i barnehagens lekemiljøer?" fournal for Research in Arts and Sports Education, Special Issue: Fysisk aktivitet, kropp og bevegelse ibarnehagen, 
risky play in the indoor environment of Early Childhood Education and Care settings (ECEC). The study is based on video observation of 65 children aged 3-5 years, from seven ECEC centers, during periods when the children were free to play as they wished. The video observations were conducted in two phases: Autumn 2017 (T1) and Autumn 2018 (T2), and the final data material consists of 770 video observations of 2 minutes each. Based on the observations in $\mathrm{T} 1$, an intervention was carried out to strengthen the existing physical play environments. The intervention was developed and implemented as a collaboration between the researchers and staff in the participating center. The effects of the intervention were observed in T2. The data material was analyzed with descriptive statistics and regression analyzes. The results show that children engaged in risky play indoors, especially with great heights and rough-and-tumble play, and that the risky play mainly took place in tumbling spaces and in cubbies. Results related to the intervention show that the ECEC centers that established an integrated tumbling space had an increase in risky play indoors. In addition, the results show that both girls, boys and children of different ages used the tumbling spaces for risky play after the intervention. Overall, this study demonstrates opportunities to create exciting and more varied play opportunities indoors in ECEC.

Keywords: ECEC; play environment; risky play; tumble space

\section{Innledning}

Norske barnehagebarn tilbringer mye tid innendørs. Det finnes ikke helt presise timetall, men ulike studier tilsier en giennomsnittlig utetid på 1,5-2 timer per dag gjennom kaldere årstider (Kaarby \& Tandberg, 2017; Moser \& Martinsen, 2010; Nilsen, Anderssen, Resaland et al., 2019; Nilsen, Anderssen, Ylvisaaker et al., 2019). Det betyr at norske barnehagebarn er innendørs mesteparten av dagen, i store deler av året. I Rammeplan for barnehager heter det at barnehagen skal bidra til at «at alle barn får muligheter til å oppleve trivsel, glede og mestring ved allsidige bevegelseserfaringer, inne og ute, året rundt» (Kunnskapsdepartementet, 2017, s. 49). For å gi barna disse mulighetene står lek helt sentralt. I denne studien er vårt teoretiske utgangspunkt basert på forståelser som at lek er subjektivt frivillig og ubegrenset, indre motivert, lystbetont og spontant (Storli \& Sandseter, 2019). Studien baserer seg også på at lek kan deles inn i kategorier ut fra hvordan leken fremstår for observatøren. Å kategorisere ulike former for lek er ikke lett - fra barns ståsted kanskje til og med unødvendig - men for forskere og barnehageansatte kan det både ha praktisk og forskningsmessig verdi å forsøke å avgrense og kategorisere lek. Basert på tidligere forskning har vi tatt utgangspunkt i følgende fire lekkategorier til sammenligning og analyse: Funksjonell lek (for eksempel løping, sykling, klatring, aking, rulling, kasting), konstruksjonslek (for eksempel å lage sandslott, bygge hytter og gjemmesteder, tegning, leke med løsmaterialer som pinner, kongler, småstein), symbolsk lek (for eksempel rollelek, dramalek, sosial lek) og blandet lek (når barn kombinerer flere typer lek uten at en av dem er dominerende) (Sandseter, 2020). For ytterligere å undersøke barns lekeerfaringer og -muligheter innendørs, legger vi i denne studien til en ny kategori, nemlig risikofylt lek. 


\section{Risikofylt lek - hva er det og hvorfor bør barnehager fremme det?}

Risikofylt lek er aktiviteter hvor barn frivillig oppsøker spenning og (moderat) fare (Brussoni et al., 2015; Sandseter, 2010b; Stephenson, 2003). At barn frivillig oppsøker fare kan høres paradoksalt ut, men slike aktiviteter fortsetter mennesker med hele livet, som for eksempel klatring, balansering eller utforkjøring på ski eller sykkel (Breivik et al., 2017). Denne formen for lek kan tolkes på ulikt vis, men mye tyder på at 'belønningen', for eksempel i form av skrekkblandet fryd eller mestringsfølelse, er så stor at den oppveier muligheten for negative konsekvenser (Apter, 2007; Zuckerman, 2009). Samtidig er denne avveiningen i høy grad subjektiv, og studier viser at det er store individuelle forskjeller i hvordan hver enkelt vurderer og opplever ulike typer risiko (Morrongiello \& Lasenby, 2006; Zuckerman, 2009).

Én definisjon av risikofylt lek som har blitt mye brukt i barnehageforskning er «spennende og utfordrende lek som involverer usikkerhet og en risiko for fysisk skade» (Sandseter, 2014, s. 14). Her er det viktig å presisere at risikofylt lek også kan ha positive utfall, som for eksempel opplevelser av glede og mestring, både på kort og lang sikt (Sandseter \& Kleppe, 2019). Det er også utviklet underkategorier som konkretiserer hva selve risikoen, det vil si den mulige negative konsekvensen, er knyttet til: 1) Lek med store høyder - for eksempel klatring, hopping eller balansering med fare for fall; 2) Lek med høy hastighet - ukontrollert hastighet som kan føre til en kollisjon med noe (eller noen), for eksempel sykling i høye hastigheter, aking (vinter); 3) Lek med farlige verktøy som øks, sag, kniv, hammer eller tau med fare for kuttskader eller andre relaterte skader; 4) Lek i nærheten av farlige elementer - for eksempel nær vann eller en ildsted med fare for drukning eller brannskader; 5) Lek som involver kamp, for eksempel boltrelek, lekeslåssing eller fekting med pinner der barn kan skade hverandre; 6) Lek der barn utforsker alene eller stikker av/gjemmer seg for voksen med fare for å gå seg bort; 7) Lek med sammenstøt - barn krasjer med vilje seg selv eller en gjenstand inn i noe med fare for slagskader eller andre relaterte skader; 8) Vikarierende risiko - det vil si at barn observerer andre barn som leker risikofylt og erfarer noe av den samme spenningen ved det (Kleppe et al., 2017; Sandseter, 2009b).

I Rammeplan for barnehager står det at barnehagen skal «bidra til at barna opplever å vurdere og mestre risikofylt lek gjennom kroppslige utfordringer» (Kunnskapsdepartementet, 2017, s. 49). Å få utfolde seg i denne formen for lek kan være viktig for barn på flere måter. For det første har leken, fra deltakernes ståsted, en egenverdi. Leken trenger ingen berettigelse utover å gjøre - og å fortsette den (Carse, 1987; Pellegrini \& Smith, 1998). I tillegg innebærer risikofylt lek en mulighet til å erfare et bredt følelsesregister, inkludert nøling, frykt, spenning, glede, mestring (Coster \& Gleave, 2008; Sandseter, 2009c, 2010a). Barn referer gjerne til denne erfaringen som "kiling i magen» (Sandseter, 2010a). Det er også mye som tyder på at det å få leke med spenning og risiko ruster barn til å håndtere dette hensiktsmessig senere i livet (Brussoni et al., 2012; Kvalnes, 2017; Lavrysen et al., 2015), på samme måte som de tilegner seg, for eksempel, sosiale eller språklige ferdigheter og 
forståelse gjennom lek (Pellegrini, 1988; Stangeland, 2017). I lek kan barn prøve feile og forstå seg selv og egne begrensninger og muligheter uten alvorlige konsekvenser (Bruner, 1976; Sutton-Smith, 1997). Det finnes også indikasjoner på at overbeskyttelse i barndommen medfører større mulighet for angst i ungdom eller voksen alder (Allen \& Rapee, 2005; Clarke et al., 2013). Det vil si at barn som er forsøkt beskyttet mot all mulig risiko i barndommen opplever verden som mer skremmende eller uhåndterlig når de skal mestre dette på egen hånd, antagelig fordi de er fratatt muligheten å utvikle egne strategier og reaksjoner (Kennair et al., 2018). Den siste grunnen for å tilrettelegge for risikofylt lek i barnehagen er dens mulige positive relasjon til fysisk aktivitet. Det vil si at den belønningen barn får i form av spenning, glede eller mestring antagelig er en sentral motivasjon for å holde seg i aktivitet. Å ake er et slik eksempel. Barn kan gå opp en akebakke utallige ganger, og det er vanskelig å tenke seg like mye gåing uten den spennende aketuren ned igjen. Denne positive sammenhengen er bekreftet i empiriske studier (Kleppe, 2018b; Sandseter, 2010b).

\section{Mulige hindringer for risikofylt lek}

Til tross for mange mulige positive sider og fordeler ved risikofylt lek finnes det indikasjoner på at denne formen for lek begrenses - også i norske barnehager. Det kan være flere årsaker til det. For det første kan det henge sammen med skader, eller, kanskje heller frykten for at barn skal skade seg. Riktignok hender det at barn skader seg i barnehagen, men det er svært få alvorlige skader (Sando et al., 2017). Det meste er skader som kan håndteres av barnehageansatte, for eksempel blåmerker og skrubbsår. Det er selvfølgelig ikke ønskelig at barn skader seg, men det er vanskelig å tenke seg lekende og aktive barn uten risikoen for blåmerker og skrubbsår. For det andre finnes det tegn på at barns muligheter til å leke fritt gradvis har blitt innskrenket i tråd med et generelt økt fokus på sikkerhet i samfunnet (Ball \& Ball-King, 2011). Et rigid sikkerhetsregime med ensidig fokus på skadereduksjon er ikke forenelig med pedagogiske mål som både omhandler at barn er fysisk aktive og mestrer egne liv (Sandseter et al., 2017), slik rammeplanen krever (Kunnskapsdepartementet, 2017). En tredje mulig årsak til manglende tilrettelegging for risikofylt lek kan henge sammen med en utbredt oppfatning om at barn er naturlig aktive, særlig når de er utendørs (Truelove et al., 2018). Det vil si at man antar at bare ved å slippe barn ut vil de løpe, hoppe og klatre. Nyere studier viser for øvrig at barnehagebarn er overraskende lite fysisk aktive utendørs (Dønnestad et al., 2018; Nilsen, Anderssen, Resaland et al., 2019; Osnes \& Skaug, 2015). Spørsmålet er da hva som hindrer barn i å være fysisk aktive når de kommer utendørs? Hvis vi antar at spenning og litt risiko fungerer som motivasjon for å være fysisk aktiv, kan manglende tilrettelegging handle om barnehageansattes manglende kunnskap eller negative holdninger til risikofylt lek. Tidligere studier viser riktignok at norske barnehageansatte er positive til barns utfoldelse og risikotaking i lek (Little et al., 2012; New et al., 2005), også med de aller yngste barna (Kleppe, 2017), men når man ser på utviklingen over tid, er det tegn på at også norske barnehageansatte har blitt mer fokuserte på sikkerhet $\mathrm{i}$ 
tråd med samfunnsutviklingen generelt (Sandseter \& Sando, 2016). For barnehageansatte er balansen mellom å forhindre alvorlige skader og samtidig støtte erfaring med risikofylt lek på ingen måte en teoretisk diskusjon. Til daglig må de ta beslutninger hvor de veier muligheten for skader opp mot fordelene ved fysisk aktivitet og risikofylt lek, og dette oppleves som et dilemma (van Rooijen et al., 2020; van Rooijen \& Newstead, 2017). Skadeunngåelse er lett å måle, mens fremtidige fordeler er langt vanskeligere å dokumentere. Å kunne argumentere faglig for fordeler ved risikofylt lek innebærer dermed både å skape aksept for mulige småskader og forståelse for langsiktige fordeler.

\section{Risikofylt lek i barnehagers innemiljø og denne studiens forskningsspørsmål}

Det er gjort svært få studier som knytter risikofylt lek til barnehagers innemiljøer. I en studie med 1-3-åringer, var 1-åringene mer aktive i risikofylt lek innendørs, sammenlignet med utendørs (Kleppe, 2018a). Årsaker til dette kunne være at 1-åringene tilbrakte relativt mye tid innendørs (sammenlignet med 2- og 3-åringene i studien) og at de fysiske elementene som oftest bidrar til ulike former for risikofylt lek (klatrestativ, sklier, sykler) ikke var tilpasset de aller yngste. 2- og 3-åringene var, som $i$ andre studier, mer involvert i risikofylt lek utendørs. Utover dette har studier som forbinder fysisk miljø og risikofylt lek handlet om utemiljøet (Obee et al., 2020; Sandseter, 2009a; Waters, 2017). Det samme gjelder mulige relevante intervensjonsstudier. Det kan allikevel være verdt å merke seg enkelte resultater, som at relativt små endringer i det fysiske utemiljøet, der noen elementer kan vurderes som risikofylt, bidrar til varig økning i barns fysiske aktivitet (Engelen et al., 2013).

Studier som undersøker innemiljøene mer generelt, viser at innendørs lekemiljøer er mest tilrettelagt for stillesittende aktiviteter, for eksempel bordaktiviteter og konstruksjonslek (Osnes \& Skaug, 2015; Sandseter, 2020). Studier som undersøker fysisk aktivitet, indikerer noe av det samme, da de viser at barns løping, hopping, jaging og lignende, øker i utetiden (Nilsen, Anderssen, Resaland et al., 2019; Nilsen, Anderssen, Ylvisaaker et al., 2019; Osnes \& Skaug, 2015). I tillegg finner studier som følger barn gjennom året at barn er mer fysisk aktive deler av sommerhalvåret, det vil si i perioder hvor barnehagebarn vanligvis tilbringer mer tid ute (Nilsen, Anderssen, Ylvisaaker et al., 2019). Dette tyder på at barns muligheter til å være fysisk aktive er mer begrenset i innemiljøet. Det er dermed stort potensiale for å øke barns daglige fysiske aktivitet ved å tilrettelegge for det $\mathrm{i}$ innemiliøet $\mathrm{i}$ barnehagen. Samtidig viser forskningsgjennomgangen at det generelt er mangel på kunnskap om innendørs risikofylt lek i barnehagen. På denne bakgrunnen har våre forskningsspørsmål vært:

1. Hva slags risikofylt lek foregår i barnehagens innemiljø og hvor foregår den?

2. Hvordan påvirker en intervensjon (med hensikt å styrke barnehagens lekemiljø) risikofylt lek i innemiljøet? 


\section{Metode}

Denne studien springer ut fra prosjektet EnCompetence (DMMH, u.å.). Prosjektets mål har vært å utvikle ny kunnskap som kan fremme lek og bidra til høyere kompetanse i planlegging og utvikling av barnehagers fysiske lekemiljø. Prosjektet har vært treårig, finansiert av Norges forskningsråd (NFR) og godkjent av Norske samfunnsvitenskapelige datatjenester (NSD). Prosjektet er utformet som et designeksperiment (Hartas, 2010), hvor forskere og barnehageansatte i samarbeid har utviklet, testet og evaluert kunnskap og intervensjoner gjennom en syklisk prosess. Prosjektet er gjennomført i nært samarbeid med tre barnehageeiere og ansatte i de deltakende barnehagene, og prosessen har vært delt inn i fire faser: 1) Observasjon i barnehagene $(\mathrm{T} 1), 2)$ kunnskapsutvikling og intervensjon, 3) ny runde med observasjon (T2) og 4) videre kunnskapsutvikling og formidling, blant annet utvikling av en nettressurs (barnehagemiljo.no). Alle deltakende barnehager gjennomførte intervensjonen våren 2018. I denne artikkelen undersøker vi effekten av intervensjonen ved å sammenligne data fra $\mathrm{T} 1$ og T2.

\section{Deltagere}

Barnehagene som deltok i prosjektet, ble strategisk valgt blant barnehageeiernes barnehager. Barnehagene ble valgt for å sikre en variasjon i alder på bygget, antall barn, organiseringsform og fysisk miljø. For utfyllende informasjon om barnehagene, se Dahl (2020). Barnehagene måtte ønske å delta i prosjektet og ha en barnehagelærer som kunne delta i prosjektet som medforsker. Totalt deltok åtte barnehager i prosjektet, men i denne studien benyttes observasjoner fra syv barnehager, årsaken beskrives under avsnittet om intervensjonen.

I hver av barnehagene ble fem gutter og fem jenter tilfeldig valgt blant tre- og fireåringene til T1, hvor foreldrene hadde samtykket til deltagelse. I en av barnehagene var kun fire jenter tilgjengelig for deltagelse, og en ekstra gutt ble derfor rekruttert i denne barnehagen. Da T2 ble gjennomført, ett år etter T1, hadde fire av de 70 barna som deltok i T1 byttet barnehage. Et barn ble i tillegg ekskludert av etiske hensyn. Totalt består derfor utvalget i denne artikkelen av 65 barn, 33 jenter og 32 gutter fra syv barnehager. Ved T1 hadde barna en gjennomsnittsalder på 3,8 år (st. avvik =0,6), mens gjennomsnittsalderen ved T2 var 4,7 år (st. avvik $=0,6$ ).

\section{Etiske hensyn}

Man må ta spesielle etiske hensyn i forskning som involverer barn og unge (Fine \& Sandstrom, 1988). Et av disse hensynene er behovet for å få informert samtykke fra både foreldrene og barna. Informert samtykke fra foreldre ble samlet gjennom deres underskrift etter å ha presentert dem skriftlig informasjon om prosjektet og hvordan data skulle håndteres og formidles. Når det gjelder barns eget samtykke, er det viktig å sikre at de forstår både sin egen og forskerens rolle under datainnsamlingen, og at de når som helst kan trekke seg fra prosjektet (Grieg et al., 2007). 
Barnehagelærerne som var medforskere i dette prosjektet, og som kjente barna godt, forklarte hvert barn på en forståelig måte hvordan observasjonene skulle bli gjennomført og informerte dem om deres rett til å trekke seg når som helst. I løpet av innsamlingen av videoobservasjoner tok vi etiske hensyn ved at vi ikke filmet barnet i situasjoner som for eksempel toalettbesøk, klesskift og lignende. I situasjoner hvor barn ga uttrykk for, enten med kroppsspråk eller verbalt, at de ikke ville filmes, stoppet vi også filmingen og slettet opptaket. Alle videoobservasjonene ble lagret på eksterne harddisker med kryptert passordbeskyttelse, hvor kun forskerne i prosjektet hadde passord, og i analysene ble det brukt en kode for hvert barn slik at de ikke kan identifiseres. I all rapportering av resultater fra prosjektet er barna anonymisert.

Prosjektet er meldt til Norsk senter for forskningsdata (NSD).

\section{Intervensjonen - Integrerte tumleareal i det fysiske innemiliøet}

Vi utviklet intervensjonene basert på resultater fra T1 og workshops med forskere, barnehagelærere, arkitekt og landskapsarkitekt. Resultatene fra T1 viste at barna manglet muligheter for funksjonell lek i innemiljøet (Storli \& Sandseter, 2019). Funksjonell lek kan være for eksempel, løping, sykling, klatring, aking, rulling og kasting (Sandseter, 2020), og målene for intervensjonen skulle dermed dreie seg om å styrke barns muligheter for slik lek. Basert på forståelsen over vil spenning eller fare kunne være en del av funksjonell lek, og intervensjonen innendørs har derfor vært interessant for vår undersøkelse av risikofylt lek.

En av de deltagende barnehagene hadde et såkalt tumleareal vedT1. Dette var et sted for forskjellige typer fysisk lek med myke overflater, puter og gymnastikkutstyr. Dette arealet viste lovende muligheter for å fremme funksjonell lek, trivsel og fysisk aktivitet $\mathrm{i}$ innemiljøet. Andre barnehager hadde også spesialiserte rom for fysisk aktivitet, men disse var plassert utenfor avdelingen/basen, de ble delt med andre grupper og måtte bestilles på forhånd. Tumlearealet som var en integrert del av avdeling/base ble brukt mye oftere enn de spesialiserte rommene, og kan derfor forventes å ha større innvirkning på barna i hverdagen. Basert på dette, besto intervensjonen i fem av de deltakende barnehagene dermed å etablere tumleareal.

Selv om intervensjonene var bygget på samme kunnskapsbase, var intervensjonen unik i hver av de deltakende barnehagene. Tumlearealene i de ulike barnehagene ble ganske forskjellige siden de var i ulike bygninger, med ulike romløsninger, gruppering av barn og materiell til funksjonell lek. Alle tumlearealene hadde imidlertid en del felles, som myke overflater, matter og noen større materialer som barn kunne bruke til funksjonell lek (bilde 1-2). En viktig ressurs med tumlearealet var at det var integrert i avdelingen, det vil si at rommet var en del av avdelingen/ basen og tilgjengelig for barn gjennom dagen, samtidig som rommet heller ikke skulle kunne lukkes helt og dermed oppleves som en 'trykk-koker' av støy og kaos (bilde1-2). 


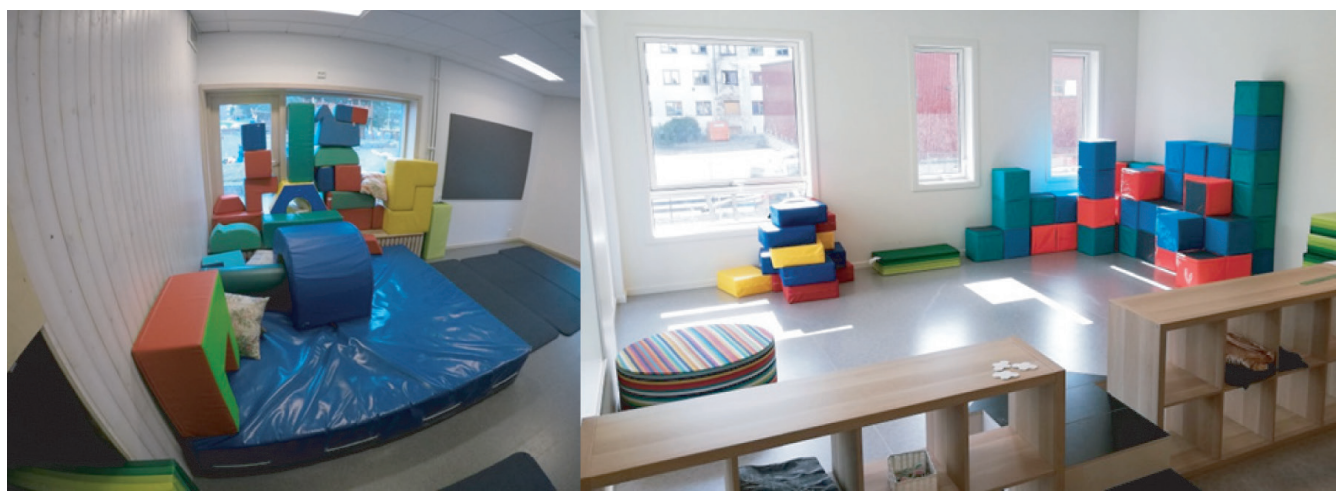

Bilde 1: Tumleareal i deltagerbarnehage Bilde 2: Tumleareal i deltagerbarnehage

For å undersøke effekten av å etablere tumleareal på barns risikofylte lek ble barna plassert i intervensjonsgruppa eller kontrollgruppa. Plassering av barn i intervensjonsgruppe eller kontrollgruppe var ikke tilfeldig, og var avhengig av om avdelingen de gikk på valgte å etablere tumlerom. Barna som gikk fra å ikke ha tilgang til tumleareal på T1, til å ha tilgang ved T2, ble plassert i intervensjonsgruppa. Kontrollgruppa bestod av barn som ikke hadde tilgang til tumleareal på noen av datatidspunktene og barn som hadde tilgang til tumleareal på begge datatidspunkt. En barnehage hadde tumleareal på T1, men ikke påT2. Den passer dermed hverken i kontrollgruppa eller intervensjonsgruppa og er utelatt i denne studien. En oversikt over de deltakende institusjonene og intervensjonene er presentert i tabell 1 .

Tabell 1. Tumleintervensjoner i de deltagende barnehagene

\begin{tabular}{|c|c|c|}
\hline Barnehage & Tumleintervensjon & Gruppe \\
\hline A & $\begin{array}{l}\text { Tumleareal ble etablert i begge deltagende } \\
\text { avdelinger. }\end{array}$ & Intervensjonsgruppe \\
\hline $\mathrm{B}$ & $\begin{array}{l}\text { Et tumleareal ble etablert i et fellesrom utenfor } \\
\text { avdelingen. }\end{array}$ & $\begin{array}{l}\text { Et barn hadde tilgang til dette arealet under } \\
\text { observasjonene i } 2 \text {. Dette barnet ble plassert } \\
\text { i intervensjonsgruppa, mens de andre barna er } \\
\text { i kontrollgruppa. }\end{array}$ \\
\hline $\mathrm{C}$ & Tumleareal ble etablert på avdelinga. & Intervensjonsgruppe \\
\hline $\mathrm{D}$ & Barnehagen hadde tumleareal i både $\mathrm{T} 1$ og $\mathrm{T} 2$. & Kontrollgruppe \\
\hline $\mathrm{E}$ & Ingen tumleintervensjon. & Kontrollgruppe \\
\hline $\mathrm{F}$ & $\begin{array}{l}\text { Tumleareal ble etablert på avdelinga, men det } \\
\text { var låst og utilgjengelig to observasjonsdager. }\end{array}$ & $\begin{array}{l}\text { Barna med tilgang til arealet er i } \\
\text { intervensjonsgruppa, mens barna uten tilgang } \\
\text { til arealeter i kontrollgruppa. }\end{array}$ \\
\hline G & $\begin{array}{l}\text { Et tumleareal ble etablert i en av de to } \\
\text { avdelingene som deltok i prosjektet. }\end{array}$ & $\begin{array}{l}\text { Barna med tilgang til arealet er i } \\
\text { intervensjonsgruppa, mens barna uten tilgang } \\
\text { til arealet er i kontrollgruppa. }\end{array}$ \\
\hline
\end{tabular}




\section{Videoobservasjoner}

Både ved T1 og T2 var målsettingen å samle inn seks videoobservasjoner på to minutter av hvert barn i perioder hvor barna kunne leke fritt i barnehagens innemiljø. Barna ble informert om prosjektet, og ble ikke filmet hvis de ikke ønsket dette. Barnehagelæreren som deltok i prosjektet som medforsker gjennomførte filmingen med et lite GoPro-kamera, med støtte fra en forsker. En person som var kjent for barna ble valgt til å gjennomføre filmingen for å minimere effekten på barna av å bli observert. For å sikre tilfeldige videoobservasjoner ble det trukket to barn som ble observert hver dag. Når perioden for videoobservasjoner startet ble det første barnet filmet i to minutter, etterfulgt av en pause på seks minutter, før det andre barnet ble filmet i to minutter. Denne vekslingen mellom de to barna ble opprettholdt til seks observasjoner av hvert barn var gjennomført. Hvis observasjonsbarnet var i en situasjon hvor filming ikke kunne gjennomføres grunnet etiske hensyn (barnet ønsket ikke å bli filmet, var på toalettet, hadde slått seg osv.), ble observasjonen utsatt. Et komplett datamateriale med seks videoobservasjoner av 65 barn på to datatidspunkt ville bestått av 780 videoobservasjoner. Ti videoobservasjoner ble ekskludert fra datamaterialet. Fem videoobservasjoner ble ekskludert fordi barnet var skjult store deler av klippet, tre ble ekskludert fordi barnet var opptatt av kameraet, og to observasjoner mangler grunnet teknisk eller menneskelig feil. Det endelige datamaterialet består derfor av 770 videoobservasjoner av 65 barn fordelt på to datainnsamlinger. Den gjennomsnittlige varigheten på videoobservasjonene var 122 sekunder (st. avvik =6).

\section{Koding av risikofylt lek}

Risikofylt lek ble kodet av de tre forskerne bak denne studien, ved hjelp av Observer XT 12.5 (Noldus), analyse- og styringsprogramvare for observasjonsdata (Zimmerman et al., 2009). Denne programvaren gir mulighet for koding sekund for sekund av videoer, som betyr at vi kunne kode forekomster og varighet av risikofylt lek. Vi kodet hver vår del av videomaterialet uavhengig av hverandre, med utgangspunkt i etablerte kategorier av risikofylt lek (Sandseter, 2014; Sandseter \& Kleppe, 2019):

- Lek med stor høyde

- Lek med stor fart

- Lek med farlige redskaper

- Lek nær farlige elementer

- Lek som innebærer kamp/boltrelek og lekeslåssing

- Lek der barna kan forsvinne / gå seg bort

- Lek med sammenstøt

- Vikarierende risiko

Ettersom risikofylt lek ble kodet sekund-for-sekund i hver av videoobservasjonene, hadde vi ikke grunnlag for å teste reliabilitet mellom koderne med typiske statistiske metoder, for eksempel Kappa, korrelasjoner eller ICC. For å sjekke samsvar mellom hvordan vi kodet risikofylt lek, gjorde vi derfor et tilfeldig utvalg av hverandres 
kodede materiale og vurderte kritisk om vi var enige i kodingen som var gjort. Blant de 137 observasjonene som var kodet med innendørs risikofylt lek, ble 54 observasjoner vurdert av en av de andre. I 44 av disse observasjonene (81\%) ble det ikke kommentert på den opprinnelige kodingen. I 7 av observasjonene (13\%) ble det kommentert på start- eller sluttidspunkt for kodingen. I 3 observasjoner (6\%) handlet kommentarer om hvilken kategori som var mest passende. De 10 observasjonene med kommentarer ble gjennomgått i fellesskap av alle de tre forskerne for å oppnå en gjensidig forståelse av bruken av kategorier og når de skal starte eller stoppe koding. Etter disse diskusjonene ble det gjort mindre justeringer av hele utvalget av observasjoner for å sikre en konsekvent bruk av kategoriene. I dette materialet ble det ikke observert, og dermed heller ikke kodet, 'lek nær farlige elementer' og 'lek der barna kan forsvinne/gå seg bort'. Disse to kategoriene er derfor utelatt fra videre analyser.

\section{Koding av fysisk miljø}

Kategorier for steder, det vil si hvor barna kunne oppholde seg i barnehagens innemiljø, ble utviklet basert på en tidligere studie (Acer et al., 2016) og diskusjoner i prosjektgruppa om utformingen av det fysiske innemiljøet $\mathrm{i}$ barnehagene som deltok. Steder i det fysiske miljøet ble kodet sekund-for-sekund ved hjelp av Observer XT 12.5 (Noldus).

- Lekesoner: Steder spesielt tilrettelagt for lek med materialer som byggematerialer, utkledningstøy, kjøkkenutstyr, lekedyr osv.

- Åpent gulvareal: Steder mellom andre soner og møbler som ikke er spesifikt kodet for en type lek.

- Bord: Bord, både i barnehøyde og i voksenhøyde.

- Tumleareal: Areal med mykt underlag, store konstruksjonsmaterialer for kroppslig lek integrert $\mathrm{i}$ avdelingen/basen.

- Garderobe: Fin- og grovgarderober for oppbevaring av klær og utstyr.

- Spesialrom for fysisk aktivitet: Store rom spesifikt utformet for fysisk aktivitet utenfor avdelingen/basen.

- Bad:Toaletter og stellerom.

- Vinduskarmer:Vindusposter.

- Rom-i-rommet: Faste installasjoner som kuber og huler.

\section{Analyse}

For å beskrive forekomst og former for risikofylt lek i observasjonene og hvor barna oppholdt seg i det fysiske miljøet har vi brukt deskriptiv statistikk. Vi har valgt å analysere de to datainnsamlingstidspunktene både hver for seg og sammenslått. Å analysere T1 og T2 sammenslått har vi gjort med bakgrunn i at det er første gangen denne formen for kartlegging giøres og vi har hatt behov for så mange observasjoner som mulig. Vi antar at T1 og T2 sammenslått utgjør et mest mulig generelt og gjenkjennbart bilde på både god og manglende innendørs tilrettelegging for risikofylt lek 
i norske barnehager. For å undersøke sammenhengen mellom risikofylt lek og ulike steder i barnehagens innemiljø, kjønns- og aldersforskjeller, og effekten av tumleintervensjonen på risikofylt lek, har vi brukt flernivå regresjonsanalyser (Hox, 2010), spesifikt «random intercept models» (Mehmetoglu \& Jakobsen, 2016). Avhengig variabel $i$ analysen er andel risikofylt lek i observasjonen. Denne analysestrategien giør det mulig å kontrollere for den hierarkiske strukturen på datamaterialet, hvor det er flere observasjoner på hvert barn og i hver barnehage. Flernivå regresjonsanalyser tar høyde for dette, og øker derfor nøyaktigheten av prediksjonene (Gelman, 2006).Utvalget er gruppert $\mathrm{i}$ tre nivå: Nivå 1: observasjonsnivået $(\mathrm{N}=770)$, Nivå 2 : barnenivået $(\mathrm{N}=65)$, Nivå 3: barnehagenivået $(\mathrm{N}=7)$. For å vurdere hvor mange nivå som skulle benyttes i analysen ble intraklasse-korrelasjon (Mehmetoglu \& Jakobsen, 2016) med en grense på $5 \%$ variasjon brukt. Kalkulasjon av intraklasse-korrelasjonen for risikofylt lek estimerer at $7 \%$ av variasjonen ligger på barnenivået, og videre at $3 \%$ av variasjonen ligger på barnehagenivået. En modell med to nivåer, observasjonsnivået og barnenivået, benyttes derfor i alle analyser. Analysene består av en stegvis inklusion av de uavhengige variablene (Hox, 2010), hvor vi har inkludert variabler på observasjonsnivået (steder $\mathrm{i}$ innemiliøet) før variabler som ligger på barnenivået (kjønn, alder, intervensjonsgruppe, datainnsamling). Nullmodell (M0), stedsmodell (M1) og den endelige modellen med kjønn og alder (M2) presenteres i tabell 3. Deviance, Akaike's Information Criterion (AIC) og Schwarz's Bayesian Information Criterion (BIC) presenteres for å indikere hvor godt modellen passer datamaterialet og for å kunne sammenlikne de ulike modellene. Deskriptiv statistikk for variablene som benyttes i de videre analysene presenteres i tabell 2 . Til disse statistiske analysene har vi brukt SPSS 26 (IBM SPSS Statistics for Windows, Version 26.0. IBM Corp., Armonk, NY) og Stata 14.2 (StataCorp, College Station, TX, USA).

\section{Resultater}

Forekomst og former for risikofylt lek innendørs

Ved T1 lekte barna risikofylt innendørs i gjennomsnitt $4 \%$ av den observerte tiden, mens ved T2 lekte barna risikofylt innendørs i $10 \%$ av den observerte tiden (tabell 2). Som nevnt tidligere, viste resultatene fra $\mathrm{T} 1$ at barna manglet muligheter for funksjonell lek i innemiljøet (Storli \& Sandseter, 2019), i vår studie gjenspeiles dette i lav forekomst av risikofylt lek ved T1 (tabell 2 og 4). I barnehagene uten tumleareal, det vil si intervensjonsgruppa (tabell 1 ) var det i gjennomsnitt $2 \%$ risikofylt lek inne (tabell 4). Underkategoriene blir generelt små, inkludert endringer fra T1 til T2, men lek med høyde og boltrelek/lekeslåssing har også størst økning og blir også de største kategoriene sammenslått (tabell 2). For å kunne si noe mer generelt har vi slått sammen T1 og T2 som et uttrykk for både god og manglende tilrettelegging og får da at barna lekte risikofylt i $7 \%$ av den observerte tiden i innemiljøet (tabell 2). Den totale andelen risikofylt lek (7\%) var fordelt på underkategoriene lek med stor høyde $(3 \%$, st. avvik $=14)$, lek med stor fart $(1 \%$, st. avvik $=2)$, lek som innebærer kamp, 
boltrelek og lekeslåssing $(3 \%$, st. avvik $=15)$, lek med farlige redskaper $(0,4 \%$, st. avvik = 5), lek med sammenstøt $(0,2$, st. avvik $=4)$ og vikarierende risiko $(0,1 \%$, st. avvik = 2).

Barna oppholdt seg mest på lekesoner $(26 \%$, st. avvik = 41), åpent gulvareal $(26 \%$, st. avvik $=38)$ og bord $(21 \%$, st. avvik = 38). Den øvrige tiden var fordelt på tumleareal $(12 \%$, st. avvik = 32), garderobe $(7 \%$, st. avvik = 23), spesialrom for fysisk aktivitet $(3 \%$, st. avvik = 17) og andre steder som bad, vinduskarmer og rom i rommet $(5 \%$, st. avvik $=19)($ tabell 2$)$.

Tabell 2. Deskriptiv statistikk $(\mathrm{N}=770)$

\begin{tabular}{lccccc}
\hline Variabel & $\begin{array}{c}\text { Gjennomsnitt ved } \\
\text { T1 og T2 }\end{array}$ & $\begin{array}{c}\text { Gjennomsnitt } \\
\text { T1-T2 } \\
\text { sammenslått }\end{array}$ & Standardavvik & Min & Max \\
\hline Alder & $3,8-4,7$ & 4,2 & 0,7 & 2,9 & 5,8 \\
\hline Risikofylt lek \% & $4-10$ & 7 & 21 & 0 & 100 \\
- Stor høyde \% & $1,4-5,2$ & 3,3 & 14 & 0 & 100 \\
- Stor fart \% & $0-0,1$ & 0,1 & 2 & 0 & 58 \\
- Farlige redskaper \% & $0,6-0$ & 0,3 & 5 & 0 & 100 \\
- Nær farlige elementer \% & $0-0$ & 0 & 0 & 0 & 0 \\
- Boltrelek og lekeslåssing \% & $1,8-4,1$ & 3,0 & 15 & 0 & 100 \\
- Forsvinne/gå seg bort \% & $0-0$ & 0 & 0 & 0 & 0 \\
- Sammenstøt \% & $0,1-0,2$ & 0,2 & 4 & 0 & 100 \\
- Vikarierende risiko \% & $0,1-0$ & 0,1 & 2 & 0 & 41 \\
\hline Steder & & & & & \\
- Lekesoner \% & $23,8-28,7$ & 26 & 41 & 0 & 100 \\
- Åpent gulvareal \% & $34,9-15,6$ & 26 & 38 & 0 & 100 \\
- Bord \% & $20-21,6$ & 21 & 38 & 0 & 100 \\
- Tumleareal \% & $5,6-19$ & 12 & 32 & 0 & 100 \\
- Garderobe \% & $6,8-6,7$ & 7 & 23 & 0 & 100 \\
- Spesialrom FA \% & $1,5-5,7$ & 3 & 17 & 0 & 100 \\
- Andre steder \% & $6,5-3,4$ & 5 & 19 & 0 & 100 \\
\hline
\end{tabular}

Hvor foregår den risikofylte leken $\mathrm{i}$ innemiljøet?

Analysen av sammenhengen mellom ulike steder i barnehagens innemiljø og barns risikofylte lek viste at tumlearealet, garderoben og spesialrom for fysisk aktivitet var steder hvor det foregikk mer risikofylt lek enn andre steder i innemiljøet (tabell 2 og 3). Basert på den endelige regresjonsanalysen (M2 i tabell 3), kan vi estimere at når barn er i tumlearealet hele observasjonen (100\%), vil dette føre til $27 \%$ mer risikofylt lek. Til sammenlikning estimerer modellen at andelen risikofylt lek øker med $14 \%$ når barnet er i spesialrom for fysisk aktivitet, og med $13 \%$ når barn er i garderoben. De øvrige stedskategoriene var ikke signifikant sammenhengende med andel risikofylt lek i 
observasjonen. Eldre barn lekte litt mer risikofylt lek (1,8 \% mer per år), mens det var ikke forskjell mellom gutter og jenter i hvor mye de lekte risikofylt i innemiljøet.

Tabell 3. Regresjonsmodeller for risikofylt lek og steder i innemiljøet ( $=770$ observasjoner)

\begin{tabular}{lccc}
\hline & M0 & M1 & M2 \\
\hline Fast del & Koeff, (st. avvik) & Koeff, (st. avvik) & Koeff, (st. avvik) \\
Konstant & $7(1)$ & $2(4)$ & $-6(5)$ \\
Lekesoner & & $0,00(0,04)$ & $0,00(0,04)$ \\
Åpent gulvareal & & $0,02(0,04)$ & $0,02(0,04)$ \\
Bord & & $-0,02(0,04)$ & $-0,03(0,04)$ \\
Tumleareal & & $0,27(0,04)^{\star \star \star}$ & $0,27(0,04)^{\star \star \star}$ \\
Garderobe & & $0,13(0,05)^{\star \star}$ & $0,13(0,05)^{\star \star}$ \\
Spesialrom FA & & $0,14(0,05)^{\star \star}$ & $0,14(0,06)^{\star \star}$ \\
Alder & & & $1,8(1,1)^{\star}$ \\
Kjønn $(0=$ jente) & & & $0,9(1,7)$ \\
\hline Tilfeldig del & & & \\
Nivå 1 Varianse & & $350(19)$ & $349(19)$ \\
Nivå 2 Varianse & $622(12)$ & $16(8)$ & $15(8)$ \\
Deviance & 6879 & 6725 & 6721 \\
AIC & 6885 & 6743 & 6743 \\
BIC & 6899 & 6785 & 6794 \\
\hline
\end{tabular}

${ }^{\star} \mathrm{p}<0,05 ;{ }^{\star \star} \mathrm{p}<0,01 ;{ }^{\star \star \star} \mathrm{p}<0,001$.

Hvilken effekt hadde tumleintervensjonen på barns risikofylte lek?

Tabell 4 viser deskriptiv statistikk for de to gruppene delt på de to datainnsamlingene.

Tabell 4. Deskriptiv statistikk for kontroll- og intervensjonsgruppa

\begin{tabular}{lcccc}
\hline & \multicolumn{2}{c}{ Kontrollgruppe } & \multicolumn{2}{c}{ Intervensjonsgruppe } \\
\hline Datainnsamling & T1 & T2 & T1 & T2 \\
Antall barn & 36 & 36 & 29 & 29 \\
Antall gutter & 15 & 15 & 17 & 17 \\
Antall observasjoner & 216 & 208 & 173 & 173 \\
Alder, gjennomsnitt år (st. avvik) & $3,8(0,5)$ & $4,8(0,5)$ & $3,7(0,6)$ & $4,6(0,6)$ \\
Risikofylt lek, gjennomsnitt \% (st. avvik) & $6(20)$ & $8(23)$ & $2(10)$ & $12(27)$ \\
Tumleareal, gjennomsnitt \% (st. avvik) & $10(30)$ & $7(24)$ & $0(0)$ & $34(46)$ \\
\hline
\end{tabular}

Intervensjonsgruppa hadde $2 \%$ risikofylt lek på første datainnsamling, og $12 \%$ risikofylt lek innendørs på andre datainnsamling (tabell 4). For å undersøke om intervensjonsgruppa hadde en signifikant større økning i andel risikofylt lek fra første til andre datainnsamling enn kontrollgruppa, ble flernivå regresjonsanalyse benyttet. 
Som for analysen av steder i innemiljøet ble en nullmodell (M0) først kjørt. Deretter ble kjønn, alder, gruppetilhørighet og datainnsamlingstidspunkt lagt til (M1). I neste steg (M2) ble et interaksjonsledd for gruppetilhørighet og datainnsamlingstidspunkt inkludert. Denne analysen (tabell 5) viser at intervensionsgruppa hadde en signifikant større økning i andel risikofylt lek $(p=0,006)$, og det estimeres at intervensjonsgruppa hadde $8 \%$ større økning i andel risikofylt lek i innemiljøet fra første til andre datainnsamling, sammenliknet med kontrollgruppa.

Tabell 5. Regresjonsmodeller intervensjonseffekt $(\mathrm{N}=770$ observasjoner $)$

\begin{tabular}{lccc}
\hline & M0 & M1 & M2 \\
\hline Fast del & Koeff., (st. avvik) & Koeff., (st. avvik) & Koeff., (st. avvik) \\
Konstant & $7(1)$ & $0(7)$ & $1,5(7,0)$ \\
Alder & & $1,0(1,8)$ & $1,0(1,8)$ \\
Kjønn $(0=$ jente) & & $1,4(2,1)$ & $1,4(2,1)$ \\
Intervensjonsgruppe & & $-0,1(2,1)$ & $-4,1(2,5)$ \\
Andre datainnsamling & & $4,8(2,3)^{\star}$ & $1,2(2,6)$ \\
Gruppe Tidspunkt & & & $8,0(2,9)^{\star \star}$ \\
\hline Tilfeldig del & & & \\
Nivå 1 Varianse & $422(23)$ & $413(22)$ & $349(19)$ \\
Nivå 2 Varianse & $29(12)$ & $30(12)$ & $15(8)$ \\
Deviance & 6879 & 6863 & 6856 \\
AIC & 6885 & 6877 & 6872 \\
BIC & 6899 & 6910 & 6909 \\
\hline
\end{tabular}

${ }^{\star} \mathrm{p}<0,05 ;{ }^{\star \star} \mathrm{p}<0,01$

For å undersøke eventuelle kjønns- og aldersforskjeller i effekten av intervensjonen på andel risikofylt lek ble regresjonsanalyser med interaksjonsledd for datatidspunkt og kjønn/alder utført for intervensjonsgruppa ( $\mathrm{N}=346$ observasjoner). Barna ble ett år eldre fra første til andre datainnsamling (tabell 4) og alder hadde en liten effekt på andelen risikofylt lek i observasjonstiden, det vil si 1,8 \% pr år (tabell 3). Men når vi kontrollerer for intervensjonen (tabell 5), forsvinner effekten av alder. Det vil si at intervensjonen hadde betydning for andelen risikofylt lek i observasjonstiden uavhengig av hvor gamle barna var ved observasjonstidspunktet. Analysene viser heller ingen signifikante forskjeller mellom gutter og jenter, i hvordan det å få tilgang på tumlearealet påvirket hvor mye risikofylt lek som foregikk (tabell 5). Både gutter, jenter, eldre og yngre barn ser altså ut til å ta i bruk tumlearealet til risikofylt lek etter intervensjonen.

\section{Diskusjon}

I denne studien har vi dokumentert at 3-5-åringer involverer seg i risikofylt lek innendørs. Før etablering av tumleareal lekte barna risikofylt i gjennomsnitt $4 \%$ 
av den observerte tiden, mens etter etablering av tumleareal lekte barna risikofylt i $10 \%$ av den observerte tiden (tabell 2 og 4). Hvis vi antar at de to resultatene til sammen utgjør er så generelt bilde som mulig, det vil si at det inkluderer barnehager med både god og manglende tilrettelegging, får vi at barna i denne studien involverte seg i risikofylt lek i gjennomsnitt $7 \%$ av den observerte tiden i innemiljøet (tabell 2). Resultater fra det samme datamaterialet viser at barna drev med konstruksjonslek i $36 \%$ og med symbolsk lek i $21 \%$ av den observerte tiden innendørs (Sandseter, 2020). Andelene risikofylt lek fremstår slik sett som relativt små, men, som beskrevet innledningsvis, gir tidligere studier heller ikke grunnlag for å forvente mye innendørs risikofylt lek (Nilsen, Anderssen, Resaland et al., 2019; Osnes \& Skaug, 2015; Sandseter, 2020). Ettersom dette er første gang innendørs risikofylt lek er dokumentert på denne måten, og med tanke på at vi har observert stor variasjon $i$ tilrettelegging $i$ vår studie, antar vi at våre resultater kan være gjenkjennbare $\mathrm{i}$ andre barnehager med tilsvarende innemiljøer. For øvrig, hva som er vanlig forekomst av innendørs risikofylt lek kan vi ikke si basert på denne enkeltstudien og bør undersøkes videre.

Når det gjelder underkategorier, gjør få observerte tilfeller at enkelte kategorier blir svært små. Vi må derfor være ekstra forsiktige med fortolkninger, men generelt ser vi at det forekom både lek med høyde, fart, farlige redskaper, sammenstøt, boltrelek/lekeslåssing og vikarierende risiko. At seks av åtte underkategorier er observert innendørs kan antagelig anses som relativt stor variasjon. Underkategoriene blir diskutert videre nedenfor i sammenheng med intervensjonen.

At det foregikk risikofylt lek innendørs, og med en slik variasjon, antyder at de ansatte aksepterte leken, og dette kan blant annet fortolkes utfra hvor leken foregikk: Regresjonsanalysen viser at når barn var i tumlearealet hele observasjonen økte andelen risikofylt lek med $27 \%$ (tabell 3). Til sammenligning økte andelen risikofylt lek med $14 \%$ da barnet var i spesialrom for fysisk aktivitet, og med $13 \%$ når barn var i garderoben. At andelen risikofylt lek økte på tumleareal og spesialrom for fysisk aktivitet var som forventet, men at det økte i garderoben var mer uventet. Det kan være et uttrykk for kreativ bruk av rom - både fra barns og personalets side. Tidligere studier indikerer at innendørs barnehagemiljøer i stor grad er tilrettelagt for stillesittende aktiviteter (Osnes \& Skaug, 2015). Å bruke garderoben til risikofylt lek kan dermed ses på som en kreativ (nød-)løsning. Vi observerte at ansatte bidro til risikofylt lek i garderobene, for eksempel med å lage hinderløyper. Vi kan anta at fordelen - og kanskje noe av personalets hensikt - var at leken da ikke forstyrret roligere aktivitet som typisk foregikk ellers på avdelingen.

I enkelte observasjoner forekom det også risikofylt lek i garderoben uten ansattes tilrettelegging eller uten at de var til stede, for eksempel lekeslåssing eller klatring. Dette kan antyde at barna benyttet garderoben som et 'fristed' - et sted å leke på en måte som de opplevde at de voksne ellers ville stoppe. Det er også mulig at de ansatte visste om leken, og bevisst lot den foregå uten innblanding. Dette ville ikke være uvanlig, med tanke på hvordan norsk barnehagepedagogikk er påvirket av 
Frøbels pedagogiske filosofi (Balke, 1995; Johansson, 2007), hvor voksnes innblanding i barns lek gjerne anses som unødvendig og forstyrrende. Alt i alt indikerer disse forholdene at barn har behov og interesse for å leke risikofylt, og at de vil gjøre det selv om det ikke er optimalt tilrettelagt for det.

Når det gjelder vårt andre forskningsspørsmål, viser resultatene at etablering av integrerte tumleareal hang sammen med en økning i barns risikofylte lek. Regresjonsanalysen (tabell 5) viser at intervensjonsgruppa hadde en signifikant større økning $(8 \%)$ i andel risikofylt lek $(\mathrm{p}=0,006)$, sammenlignet med kontrollgruppa. Tidligere intervensjonsstudier har vist at det skal relativt lite til for at barn blir mer fysisk aktive og engasjerer seg i risikofylt lek (Engelen et al., 2013). I tråd med dette, kan vårt resultat fortolkes som et uttrykk for at barn er naturlig fysisk aktive (Truelove et al., 2018). Barna i intervensjonsgruppa fikk tilgang til arealer og materiell som ga mulighet for fysisk aktiv lek, inkludert risikofylt lek, og de benyttet muligheten. Underkategoriene som økte mest fra første til andre datainnsamling var lek med høyde og boltrelek/lekeslåssing og disse kategoriene har også høyest forekomst totalt (tabell 2). At barn lekte med høyde innendørs kan virke overraskende, men henger særlig sammen med store myke «klosser» som ble introdusert $\mathrm{i}$ flere av barnehagene $\mathrm{i}$ forbindelse med intervensjonen og som tillot barna å bygge i høyden. Barna skapte dermed sin egen tilpassede høydelek, hvor de kunne klatre med ulik vanskelighetsgrad, eller for eksempel balansere og hoppe ned fra ulike høyder. Dette kan indikere at barna fikk frihet til å leke som de ville og at dette, koblet med godt materiell og god plass, illustrerer grunnleggende betingelser for lek (Hughes, 2010; Storli \& Sandseter, 2019). Den høye andelen boltrelek og lekeslåssing kan tolkes på tilsvarende måte, det vil si at intervensjonen bidro til at det fantes tilpassede fysiske miljøer (myke underlag og puter) og at barna fikk frihet til å boltre og lekeslåss.

I tillegg påvirket tumlearealene bredt i barnegruppa. Den positive sammenhengen mellom tilgang til tumleareal og økning i risikofylt lek var uavhengig av kjønn (tabell 5). Dette var ganske overraskende, særlig fordi boltrelek og lekeslåssing, som var populært i tumlearealene, vanligvis er dominert av gutter (Eide-Midtsand, 2007; Pellegrini, 2006; Storli, 2020). På samme måte kan man også forvente at eldre barn er mer fysisk aktive (Brown et al., 2006) og involverer seg mer i boltrelek (Pellegrini \& Smith, 1998). I vår studie fant vi en liten økning blant eldre barns involvering i risikofylt lek, (1,8 \% per år) (tabell 3), men når vi kontrollerte for intervensjonen forsvant effekten av barnets alder (tabell 5). Det vil si at alder ikke hadde betydning for om barna tok i bruk tumlearealene i intervensjonsbarnehagene. Tumlearealene fremstår slik sett som arenaer for spennende og aktiv lek både for gutter og jenter og barn i ulike aldre, og kan fortolkes som mangfoldige og inkluderende lekearenaer.

Det er sannsynlig at intervensjonens positive resultater har grunnlag i de konkrete fysiske endringene som ble gjort. I tillegg er det sannsynlig at de ansatte spilte en rolle. Selv om vi ikke har undersøkt de ansatte spesifikt i denne studien, kan resultatene 
diskuteres i vekselvirkningen mellom de fysiske endringene og de ansattes valg og handlinger. For det første ville de ansatte neppe tillatt, enn si, lagt til rette for, lek de trodde ville innebære økte muligheter for skader (Sandseter \& Sando, 2016). Tumlearealene i denne studien var derfor tilrettelagt slik at de skulle minimere muligheten for skader, det vil si at de var fylt med myke overflater, store puter og gymnastikkutstyr, som både inspirerte barn til å bruke kroppen, men som samtidig personalet skulle føle seg trygge på (bilde 1-2). Utformingen av arealene kan ha medført former for risikofylt lek som i liten grad ble oppfattet som farlige eller med høy mulighet for skade av de ansatte. Dette kunne i sin tur bidra til at de ansatte tillot mer risikofylt lek enn de ville gjort i andre miliøer. Videre er støy et kjent problem i barnehagen (Fredriksson, 2018; Lie et al., 2013) og en del ansatte ville kunne vegre seg for å aktivt legge til rette for lek som innebærer løping, herjing og roping. Tumlearealene ble derfor utformet slik at de ikke ble lukkede rom med mye støy og kaos. De ble også plassert slik at de ikke forstyrret lek som krever andre former for konsentrasjon og bevegelse. Økningen av risikofylt lek i intervensjonsgruppa kan derfor også henge sammen med at de ansatte ikke opplevde økt støy som så problematisk at de satte en stopper for aktiviteten. Til slutt, fra en mer positiv innfallsvinkel, er det også trolig at de ansatte i intervensjonsgruppa fikk en økt forståelse for innendørs fysisk aktiv lek og dermed i mindre grad enn de ansatte i kontrollgruppa prioriterte å unngå skader og støy, men heller i større grad kunne tillate, og endatil legge til rette for, innendørs risikofylt lek.

\section{Studiens begrensninger}

$\AA ̊$ avgrense og observere en spesifikk form for lek er utfordrende, det samme gjelder å dokumentere effekter av en intervensjon i praksis. I denne studien besto intervensjonen $i$ å etablere et tumleareal, men i samme tidsrom skjedde det flere endringer i barnehagene. Flere av barnehagene etablerte nye lekesoner og økte tilgjengeligheten og kvaliteten på lekematerialer. I den prosessen må vi anta at personalets kompetanse også økte og kanskje også at deres holdninger endret seg, og at dette har påvirket resultatene uten at vi kan kontrollere for det. Det skjedde også endringer mellom T1 og T2 som ikke var knyttet til prosjektet. Blant annet flyttet noen av barna til andre avdelinger innad i barnehagen, og det var endringer i personalsammensetningen. Mer kontrollerte studier hvor barnehagene ikke selv velger å etablere tumlerom og hvor ansattes handlinger i større grad blir undersøkt eller styrt er muligheter for å få en større forståelse av effekten av endringer i det fysiske miljøet, og i hvilken grad det også er nødvendig å gjøre en «intervensjon» i personalgruppa.

Totalt sett illustrerer dette kompleksiteten og kontekstavhengigheten i denne typen intervensjonsstudier, og selv om vi har et design som sannsynliggjør rekkefølgen på årsakssammenhenger, vil det fortsatt være umulig å kontrollere for alle mulige faktorer som kan påvirke utfallene. Vi er derfor varsomme med å trekke for generelle konklusjoner ut fra funnene i denne studien. 


\section{Oppsummering og implikasjoner for praksis}

I denne studien fant vi at barna lekte risikofylt i $7 \%$ av den observerte tiden i innemiljøet, og de lekte da hovedsakelig med stor høyde eller lek som innebar kamp, boltrelek eller lekeslåssing. Videre fant vi at den risikofylte leken hovedsakelig fant sted på tumleareal, i garderoben og i spesialrom for fysisk aktivitet. Resultatene fra intervensjonen viste at barnehagene som etablerte et integrert tumleareal hadde en signifikant større økning av risikofylt lek innendørs sammenlignet med de som ikke gjorde det $(8 \%, p=0,006)$. I tillegg viste resultatene at både jenter, gutter og barn $\mathrm{i}$ ulike aldre tok i bruk tumlearealene til risikofylt lek etter intervensjonen.

Implikasjoner for praksis av denne studien kan derfor, for det første, være at barnehager bør ha et integrert tumleareal. Å legge til rette for innendørs fysisk aktiv lek, inkludert risikofylt lek, vil være et godt bidrag til et mer allsidig, variert og spennende barnehagetilbud - for hele barnegruppa. En videre implikasjon kan være at barnehager bør tenke kreativt rundt de rommene de allerede har. For enkelte barnehager kan det være både praktiske og holdningsmessige innvendinger mot å utvikle et areal for fysisk aktiv- og risikofylt lek innendørs. Denne studien viser i så måte hvordan ulike, tilpassede løsninger bidro til mangfoldige og inkluderende lekearenaer. Det har trolig hatt betydning at de ansatte har erfart løsningene som trygge og at de ikke har bidratt til uro og støy. En siste implikasjon vil dermed være nødvendigheten av å jobbe parallelt med både rom og materiell, og kunnskap og holdninger, for å skape forståelse og aksept for risikofylt lek i barnehagens innemiljø.

\section{Forfatteromtale}

Rasmus Kleppe er førsteamanuensis, ved fakultet for lærerutdanning og internasjonale studier, Institutt for barnehagerlærerutdanning, OsloMet - Storbyuniversitetet, og rådgiver og forsker i barnehagestiftelsen Kanvas.

Ole Johan Sando er stipendiat ved seksjon for fysisk aktivitet og helse, Dronning Mauds Minne Høgskole for barnehagelærerutdanning, Trondheim.

Ellen Beate Hansen Sandseter er professor ved seksjon for fysisk aktivitet og helse, Dronning Mauds Minne Høgskole for barnehagelærerutdanning, Trondheim.

\section{Referanser}

Acer, D., Gözen, G., Fırat, Z. S., Kefeli, H. \& Aslan, B. (2016). Effects of a redesigned classroom on play behaviour among preschool children. Early Child Development and Care, 186(12), 1907-1925. https://doi. org/10.1080/03004430.2015.1136999

Allen, J. L. \& Rapee, R. M. (2005). Anxiety disorders. I P. J. Graham (Red.), Cognitive behaviour therapy for children and families (2. utg., s. 300-319). Cambridge University Press.

Apter, M. J. (2007). Danger: Our quest for excitement. Oneworld.

Balke, E. (1995). Småbarnspedagogikkens historie: Forbilder for vår tids barnehager. Universitetsforlaget.

Ball, D. J. \& Ball-King, L. (2011). Public safety and risk assessment. Routledge. 


\section{R. Kleppe, O. F. Sando og E. B. S. Hansen}

Breivik, G., Sand, T. S. \& Sookermany, A. M. (2017). Sensation seeking and risk-taking in the Norwegian population. Personality and Individual Differences, 119, 266-272. http://dx.doi.org/10.1016/j.paid.2017.07.039

Brown, W. H., Pfeiffer, K. A., McIver, K. L., Dowda, M., Almeida, J. M. C. A. \& Pate, R. R. (2006). Assessing preschool children's physical activity. Research Quarterly for Exercise and Sport, 77(2), 167-176. https://doi. org/10.1080/02701367.2006.10599351

Bruner, J. S. (1976). Nature and uses of immaturity. I J. S. Bruner, A. Jolly \& K. Sylva (Red.), Play: Its role in development and evolution (s. 28-63). Basic Books.

Brussoni, M., Gibbons, R., Gray, C., Ishikawa, T., Sandseter, E., Bienenstock, A., Chabot, G., Fuselli, P., Herrington, S. Janssen, I. Pickett, W., Power, M., Stanger, N., Sampson M. \& Tremblay, M. (2015). What is the relationship between risky outdoor play and health in children? A systematic review. International Fournal of Environmental Research and Public Health, 12(6), 6423-6454. http://dx.doi.org/10.3390/ ijerph120606423

Brussoni, M., Olsen, L. L., Pike, I. \& Sleet, D. A. (2012). Risky play and children's safety: Balancing priorities for optimal child development. International fournal of Environmental Research and Public Health, 9(9), 3134-3148. https://doi.org/10.3390/ijerph9093134

Carse, J. P. (1987). Finite and infinite games. Ballantine Books.

Clarke, K., Cooper, P. \& Creswell, C. (2013). The parental overprotection scale: Associations with child and parental anxiety. Fournal of Affective Disorders, 151(2), 618-624. http://dx.doi.org/10.1016/j.jad. 2013.07.007

Coster, D. \& Gleave, J. (2008). Give us a go! Children and young people's views on play and risk-taking (Playday rapport). http://www.playday.org.uk/

Dahl, B. (2020). Hvordan kan arkitektens perspektiv bidra i planlegging og gjennomføring av endringer i barnehagebygg? I E. B. H. Sandseter \& R. Storli (Red.), Barnehagens fysiske inne- og utemiljø (s. 95-112). Universitetsforlaget.

DMMH. (u.å.). Kompetanse for utvikling av barnehagers inne- og utemiljøer (EnCompetence). https://dmmh.no/ forskning-og-utvikling/fou-prosjekter/kompetanse-for-utvikling-av-barnehagers-inne-og-utemiljoer

Dønnestad, J., Andersson, K., Bergem, M. B., Getz, M. Ø., Ida Grindland, Sperstad, J. S. \& Teinung, E. (2018). Helsefremmende praksis $i$ barnehager og skoler $i$ Groruddalen. En kartlegging av kosthold og fysisk aktivitet. https:// www.oslo.kommune.no/politikk-og-administrasjon/prosjekter/folkehelseprosjekt-i-barnehager-i-bydelgrorud/

Eide-Midtsand, N. (2007). Boltrelek og lekeslåssing: II. Om å gi gutter rom til å være gutter. Tidsskrift for norsk psykologforening, 44(12), 1467-1474. https://psykologtidsskriftet.no/fagartikkel/2007/12/boltrelekog-lekeslassing-ii-om-gi-gutter-rom-til-vaere-gutter

Engelen, L., Bundy, A. C., Naughton, G., Simpson, J. M., Bauman, A., Ragen, J., Baur, L., Wyver, S., Tranter, P. Niehues, A., Schiller, W., Perry, G., Jessup, G. \& van der Ploeg, H. P. (2013). Increasing physical activity in young primary school children - it's child's play: A cluster randomised controlled trial. Preventive Medicine, 56(5), 319-325. http://dx.doi.org/10.1016/j.ypmed.2013.02.007

Fine, G. A. \& Sandstrom, K. L. (1988). Knowing children: Participant observation with minors (Qualitative Research Methods No. 15). Sage.

Fredriksson, S. (2018). Hearing-related symptoms among women - Occurrence and risk in relation to occupational noise and stressful working conditions (Doktoravhandling, Gøteborgs universitet). GUPEA. https://gupea. ub.gu.se/bitstream/2077/55969/1/gupea_2077_55969_1.pdf

Gelman, A. (2006). Multilevel (hierarchical) modeling: What it can and cannot do. Technometrics, 48(3), 432-435. https://doi.org/10.1198/004017005000000661

Grieg, A., Taylor, J. \& MacKay, T. (2007). Doing research with children (Bd. 2). SAGE.

Hartas, D. (2010). Experimental and quasi-experimental design in educational research. I D. Hartas (Red.), Educational research and inquiry: Qualitative and quantitative approaches (s. 239-256). Continuum.

Hox, J. J. (2010). Multilevel analysis: Techniques and applications. Routledge.

Hughes, F. P. (2010). Children, play, and development (4. utg.). Sage.

Johansson, J. E. (2007). Famili, natur och fabrik, verkstad eller laboratorium: vart går barnehagepedagogiken idag? I T. Moser \& M. Röthle (Red.), Ny rammeplan - ny barnehagepedagogikk? (s. 41-56). Universitetsforlaget.

Kaarby, K. M. E. \& Tandberg, C. (2017). The belief in outdoor play and learning. Fournal of the European Teacher Education Network, 12, 25-36. http://www.jeten-online.org/index.php/jeten/article/view/127

Kennair, L. E. O., Sandseter, E. B. H. \& Ball, D. (2018). Risky play and growing up: How to understand the overprotection of the next generation. I A. B. Kaufman \& J. Kaufman (Red.), Pseudoscience: The conspiracy against science (s. 171-194). The MIT Press. 
Kleppe, R. (2017). Characteristics of staff-child interaction in 1-3-year-olds' risky play in early childhood education and care. Early Child Development and Care, 188(10), 1487-1501. http://dx.doi.org/10.1080/03 004430.2016 .1273909

Kleppe, R. (2018a). Affordances for 1- to 3-year-olds' risky play in early childhood education and care. Fournal of Early Childhood Research, 16(3), 258-275. https://doi.org/10.1177/1476718x18762237

Kleppe, R. (2018b). One-to-three-year-olds' risky play in early childhood education and care (Doktoravhandling, OsloMet - Storbyuniversitetet). ODA. https://oda.oslomet.no/handle/10642/5890

Kleppe, R., Melhuish, E. \& Sandseter, E. B. H. (2017). Identifying and characterizing risky play in the age one-to-three years. European Early Childhood Education Research fournal, 25(3), 370-385. http://dx.doi. org/10.1080/1350293X.2017.1308163

Kunnskapsdepartementet. (2017). Rammeplan for barnehagens innhold og oppgaver: Forskrift om rammeplan for barnehagens innhold og oppgaver. Udir. https:/www.udir.no/globalassets/filer/barnehage/rammeplan/ rammeplan-for-barnehagen-bokmal2017.pdf

Kvalnes, Ø. (2017). Risky play. I Fallibility at work: Rethinking excellence and error in organizations (s. 1-20). https://doi.org/10.1007/978-3-319-63318-3_1

Lavrysen, A., Bertrands, E., Leyssen, L., Smets, L., Vanderspikken, A. \& De Graef, P. (2015). Risky-play at school. Facilitating risk perception and competence in young children. European Early Childhood Education Research fournal, 25(1), 89-105. http://dx.doi.org/10.1080/1350293X.2015.1102412

Lie, A., Skogstad, M., Tynes, T., Johannessen, H. A., Nordby, K.-C., Mehlum, I. S., Arneberg, L., Engdahl, B. \& Tambs, K. (2013). Støy $i$ arbeidslivet og helse (STAMI-rapport nr. 10, årg. 14). Statens arbeidsmiljøinstitutt. http://hdl.handle.net/11250/2410987

Little, H., Sandseter, E. B. H. \&Wyver, S. (2012). Early childhood teachers' beliefs about children's risky play in Australia and Norway. Contemporary Issues in Early Childhood, 13(4), 300-316. http://dx.doi.org/10.2304/ ciec.2012.13.4.300

Mehmetoglu, M. \& Jakobsen, T. G. (2016). Applied statistics using Stata: A guide for the social sciences. Sage.

Morrongiello, B. A. \& Lasenby, J. (2006). Finding the daredevils: Development of a sensation seeking scale for children that is relevant to physical risk taking. Accident Analysis E Prevention, 38(6), 1101-1106. https://doi.org/10.1016/j.aap.2006.04.018

Moser, T. \& Martinsen, M. T. (2010). The outdoor environment in Norwegian kindergartens as pedagogical space for toddlers' play, learning and development. European Early Childhood Education Research fournal, 18(4), 457-471. http://dx.doi.org/10.1080/1350293X.2010.525931

New, R. S., Mardell, B. \& Robinson, D. (2005). Early childhood education as risky business: Going beyond what's «safe» to discovering what's possible. Early Childhood Research and Practice, 7(2). http://ecrp.uiuc. edu/v7n2/new.html

Nilsen, A. K. O., Anderssen, S. A., Resaland, G. K., Johannessen, K., Ylvisaaker, E. \& Aadland, E. (2019). Boys, older children, and highly active children benefit most from the preschool arena regarding moderate-tovigorous physical activity: A cross-sectional study of Norwegian preschoolers. Preventive Medicine Reports, 14, 100837. https://doi.org/10.1016/j.pmedr.2019.100837

Nilsen, A. K. O., Anderssen, S. A., Ylvisaaker, E., Johannessen, K. \& Aadland, E. (2019). Physical activity among Norwegian preschoolers varies by sex, age, and season. Scandinavian fournal of Medicine E Science in Sports, 29(6), 862-873. http://dx.doi.org/10.1111/sms.13405

Obee, P., Sandseter, E. B. H. \& Harper, N. J. (2020). Children's use of environmental features affording risky play in early childhood education and care. Early Child Development and Care, 1-19. http://dx.doi.org/10. $1080 / 03004430.2020 .1726904$

Osnes, H. \& Skaug, H. N. (2015). Kroppslig lek, fysisk miljø og helse i barnehagen. Første steg, 2. https:// utdanningsforskning.no/artikler/kroppslig-lek-fysisk-miljo-og-helse-i-barnehagen/

Pellegrini, A. D. (1988). Elementary-school children's rough-and-tumble play and social competence. Developmental Psychology, 24(6), 802-806. http://dx.doi.org/10.1037/0012-1649.24.6.802

Pellegrini, A. D. (2006). Rough-and-tumble play from childhood through adolescence: Differing perspectives. I D. P. Fromberg \& D. Bergen (Red.), Play from birth to twelve: Contexts, perspectives, and meanings (s. 181-186). Routledge.

Pellegrini, A. D. \& Smith, P. K. (1998). Physical activity play: The nature and function of a neglected aspect of play. Child Development, 69(3), 577-598. http://dx.doi.org/10.1111/j.1467-8624.1998.tb06226.x

Sando, O. J., Sandseter, E. B. H., Pareliussen, I. \& Egset, C. K. (2017). Injuries in Norwegian early childhood and care (ECEC) institutions. Nordisk barnehageforskning, 14. http://dx.doi.org/10.7577/nbf.1698 


\section{R. Kleppe, O. F. Sando og E. B. S. Hansen}

Sandseter, E. B. H. (2009a). Affordances for risky play in preschool: The importance of features in the play environment. Early Childhood Education Fournal, 36(5), 439-446. http://dx.doi.org/10.1007/s10643-0090307-2

Sandseter, E. B. H. (2009b). Characteristics of risky play. Fournal of Adventure Education and Outdoor Learning, 9(1), 3-21. http://dx.doi.org/10.1080/14729670802702762

Sandseter, E. B. H. (2009c). Children's expressions of exhilaration and fear in risky play. Contemporary Issues in Early Childhood, 10(2), 92-106. https://doi.org/10.2304/ciec.2009.10.2.92

Sandseter, E. B. H. (2010a). 'It tickles in my tummy!': understanding children's risk-taking in play through reversal theory. Fournal of Early Childhood Research, 8(1), 67-88. https://doi.org/10.1177/1476718x09345393

Sandseter, E. B. H. (2010b). Scaryfunny: A qualitative study of risky play among preschool children (Doktoravhandling, Norges teknisk-naturvitenskapelige universitet). NTNU Open. http://hdl.handle.net/11250/270413

Sandseter, E. B. H. (2014). Boblende glede og sug i magen. I E. B. H. Sandseter \& J.-O. Jenssen (Red.), Vilt og farlig. Om barn og unges bevegelseslek (s. 13-28). Gyldendal Akademisk.

Sandseter, E. B. H. (2020). Prosjektet EnCompetence: Bakgrunn, metode og hovedresultater. I E. B. H. Sandseter \& R. Storli (Red.), Barnehagens fysiske inne- og utemiljø. Inspirasjon til lek (s. 15-35). Universitetsforlaget.

Sandseter, E. B. H., Ball, D. J., Brussoni, M., Little, H. \& Eager, D. (2017). Risk and safety in outdoor play. I T. Waller, S. Wyver, E. B. H. Sandseter, E. Ärlemalm-Hagsér, L. Lee-Hammond \& K. Lekies (Red.), The SAGE handbook of outdoor play and learning (s. 113-126). Sage.

Sandseter, E. B. H. \& Kleppe, R. (2019). Outdoor risky play. I R. E. Tremblay, M. Boivin, R. D. Peters \& Brussoni M (Red.), Encyclopedia on early childhood development. http://www.child-encyclopedia.com/ outdoor-play/according-experts/outdoor-risky-play

Sandseter, E. B. H. \& Sando, O. J. (2016). «We don't allow children to climb trees»: How a focus on safety affects Norwegian children's play in early-childhood education and care settings. American fournal of Play, 8(2), 178-200. https://files.eric.ed.gov/fulltext/EJ1096921.pdf

Stangeland, E. B. (2017). The impact of language skills and social competence on play behaviour in toddlers. European Early Childhood Education Research fournal, 25(1), 106-121. http://dx.doi.org/10.1080/ 1350293X.2016.1266224

Stephenson, A. (2003). Physical risk-taking: Dangerous or endangered? Early Years: An International fournal of Research and Development, 23(1), 35-43. https://doi.org/10.1080/0957514032000045573

Storli, R. (2020). Boltrelek og lekeslåssing i barnehagens innemiljø. I E. B. H. Sandseter \& R. Storli (Red.), Barnehagens fysiske inne- og utemiljø (s. 67-77). Universitetsforlaget.

Storli, R. \& Sandseter, E. B. H. (2019). Children's play, well-being and involvement: how children play indoors and outdoors in Norwegian early childhood education and care institutions. International fournal of Play, 8(1), 65-78. http://dx.doi.org/10.1080/21594937.2019.1580338

Sutton-Smith, B. (1997). The ambiguity of play. Harvard University Press.

Truelove, S., Bruijns, B. A., Vanderloo, L. M., O’Brien, K. T., Johnson, A. M. \& Tucker, P. (2018). Physical activity and sedentary time during childcare outdoor play sessions: A systematic review and meta-analysis. Preventive Medicine, 108, 74-85. https://doi.org/10.1016/j.ypmed.2017.12.022

van Rooijen, M., Lensvelt-Mulders, G., Wyver, S. \& Duyndam, J. (2020). Professional attitudes towards children's risk-taking in play: Insights into influencing factors in Dutch contexts. Fournal of Adventure Education and Outdoor Learning, 20(2), 138-154. http://dx.doi.org/10.1080/14729679.2019.1568893

van Rooijen, M. \& Newstead, S. (2017). Influencing factors on professional attitudes towards risk-taking in children's play: A narrative review. Early Child Development and Care, 187(5-6), 946-957. http://dx.doi.or $\mathrm{g} / 10.1080 / 03004430.2016 .1204607$

Waters, J. (2017). Affordance theory in outdoor play. I T. Waller, E. Ärlemalm-Hagsér, E. B. H. Sandseter, L. Lee-Hammond, K. Lekies \& S. Wyver (Red.), The SAGE handbook of outdoor play and learning. Sage.

Zimmerman, P. H., Bolhuis, J. E., Willemsen, A., Meyer, E. S. \& Noldus, L. P. J. J. (2009). The Observer XT: A tool for the integration and synchronization of multimodal signals. Behavior Research Methods, 41(3), 731-735. https://doi.org/10.3758/BRM.41.3.731

Zuckerman, M. (2009). Sensation seeking. I M. R. Leary \& R. H. Hoyle (Red.), Handbook of individual differences in social behavior (s. 455-465). The Guildford Press. 